\title{
1: $150176622-150175582$
}

National Cancer Institute

\section{Source}

National Cancer Institute. 1:150176622-150175582. NCI Thesaurus. Code C44965.

Physical location of S100A8_Gene 